\title{
EDUCATIONAL INSTITUTION ACTIVITY IN THE INCLUSIVE EDUCATION PROCESS
}

\author{
Marite Rozenfelde \\ Rezekne Academy of Technologies
}

\begin{abstract}
The article provides a summary of a theoretical study on the main provisions of the activity of the educational institution's administration in creating and implementing an inclusive educational process at the institution. Inclusive education is teamwork - the responsibility and obligation shared by the whole educational institution is a challenge to the whole team of the educational institution and first of all, a challenge to the administration of the educational institution. Inclusive education can be implemented in various ways all united by organizational culture with positive perception of student diversity, an understanding that the leaders working at educational institutions with their colleagues have a central role in promoting the inclusive culture. The role of administration in the development of the inclusive educational process at an educational institution is to ensure the implementation of the norms concerning the rights of students with special needs to be included, to maintain inclusive policy in the activity of the educational institution, to provide everyone involved in the learning process with information about the special needs of the students, to allocate funds for providing for the special needs, to guarantee accessibility of the educational institution. The administration and the support specialists of the educational institution must work as a team, must develop a plan of measures for the implementation of a further inclusive education process of the educational institution, for providing the support in education where the measures for educational support include determining and assessment of the needs of a student; consultations and support for all students, including the students with special needs, professional development, consultations and support for teachers, the students' parents and the specialists; consultations of the support team specialists and services, also attracting specialists from other institutions; technical aids and equipment (if necessary); an opportunity to study using sign language and the services of an interpreter (if necessary); transportation services (if necessary, also with an accompanying person); assistant services, etc. The makeup of specialists of the support team of the educational institution - speech and language pathologist, psychologist, social pedagogue, special education pedagogue, medical specialist, etc. can vary depending on the needs and circumstances of the students of the specific educational institution. Work responsibilities of these support team professionals in the general support system of the educational institution are analyzed in the article.
\end{abstract}

Keywords: inclusive education, teamwork, support system, support team.

\section{Introduction}

According to the main inclusive education principles of UNESCO, inclusive education is considered a process where the diversity of needs of all persons who

(C) Rēzeknes Tehnologiju akadèmija, 2017

http://dx.doi.org/10.17770/sie2017vol3.2317 
study must be taken into account and satisfied by the participation of adults in the learning process, in the culture and the values of the community to decrease social rejection and poverty (UNESCO, 2005/a). The reasons for choosing the inclusive education model are: educational, for the education system must be qualitative and accessible to everyone from early childhood; social, for education must promote a change of attitude creating a society free of prejudice, discrimination and rejection; economic, for education helps improving competitiveness in circumstances where new tasks need to be solved. The aim of education is to create a better society that promotes integration and cooperation instead of status and competition (Cardona, 2011).

To create inclusive education, the content of education, the approach, structure and education strategies must be changed (Education White paper 6, 2001; NAP, 2006; World Health Organization, 2011), after which the teaching staff training systems must be developed and more funds must be allocated to it; furthermore, a global view is necessary, which would include all students, and the belief that the obligation of the general education system is to educate all persons. The aim of inclusive education is to adequately provide for the educational needs of various social groups, which can be achieved through both formal and informal education. An effective, perfect process of inclusion is the symbiosis of the inclusive activity of the educational institution and society (UNESCO, 2005/a; Education White paper 6, 2001).

Inclusive education is teamwork - the responsibility and obligation shared by the educational institution as a whole (Jonsson, 2006; Mitchell, 2010; Turnbull, Turnbull, Shank \& Smith, 2004). Inclusive education is a challenge for the whole team of the educational institution and first of all a challenge to the administration of the educational institution, for "the development and effectiveness of the educational institution is influenced by the organization philosophy of administration together accepted by the employees and the administration and by the social roles (leader, administrator) implemented in practical activity" (Celma-Zīda, 2013, 69).

The main approach - to solve the issues of creating inclusive educational institution activity and support system at three levels: administration, teachers and students (Education White paper 6, 2001; Mitchell, 2010, 11. ch.; Ras, 2008; Wolfendale, 1987), which means - support to the educational institution, support to teachers, support to students. V. Birkett also specifies that when creating a system for the activity of an inclusive educational institution, it is important to provide support to students, to teachers and to the implementation of the education programme, thus - support to the educational institution (Birkett, 2004, 14-15).

Research aim: analysis of scientific literature, determining the main conditions for the activity of an educational institution while promoting the inclusive education process. Research method: analysis of scientific literature. 


\section{The research results}

A. Dyson, based on comprehensive research of the activity of inclusive educational institutions and significant personal experience, believes that there is no unified model of how an inclusive educational institution works and what it looks like, for each country, municipality, educational institution creates their own inclusive education support system (Dyson, 2010, 79; Nìmante, 2008/c, 156). UNESCO studies also allow stating that there is no perfect model for creating a system of inclusive education but all created models are based on the main principles of inclusive education implemented in a local context (UNESCO, 2009, 144).

The following are involved in the creation of an inclusive educational institution: at the strategic level - directors of educational institutions, the responsible staff of municipalities, assistant directors, methodologists and other decision-making persons; at the tactical level - teachers of school subjects, psychologists, special education pedagogues, speech and language pathologists and other specialists, students' parents, students. For a common inclusive activity, physically and mentally orderly environment of the educational institution is necessary, the support of parents and society and where necessary, opportunities provided by the ministry of education, municipalities, social services, school support centres, higher education institutions and special education institutions.

The administration of educational institutions that begin working on creation of an inclusive educational institution must create their own educational institution support team, which through cooperation with the support staff of the municipal department of education (EDUCATION WHITE PAPER 6, 2001; Ras, 2008) implements the support necessary to all those involved in the inclusion process. The element of the inclusive education support system - the support team - must be created in the framework of each specific institution so that each one involved could help each other (Reid, 2006, 101).

In 1998, UNICEF recommendations state 12 steps in the direction to an inclusive education institution (UNICEF, 1998). These are: create learning methods that promote participation and personal development; reassess the principles of student selection and formation of classes in educational institutions; guarantee a fair examination system that would let each student demonstrate their own achievement; promote the expansion of support beyond the programme in educational institutions; expand the involvement of parents and society in education; study students' work and its relation to attendance and learning in educational institutions; pay more attention to the access to education for students from poor families and to the quality of education, to the integration of students with disabilities in normal schools; pay attention to the needs of ethnic minorities; promote early childhood development - in the widest sense using various means; 
perform sufficient centralized control of the local administration of educational institutions, including the study programme; guarantee sufficient funds to local municipalities with poor resource base (UNICEF, 1998; Jackson, Ryndak, \& Billingsley, 2003).

T. Booth has expressed an opinion that changes need to be introduced at all levels and in the whole system of the field if we wish for development of inclusive education (Booth, 2000). It is not allowed to distort facts, to pretend, hide the truth at all levels, because all this creates a deforming aspect in the development of inclusive education (Ainscow, 2004, 10). M. Ainscow and S. Miles define the criteria for the promotion of the implementation of inclusive education in educational institutions, in the system, in the policy in general (Ainscow \& Miles, 2009, 5-6).

An educational institution becomes inclusive when educational institutions have a strategy that promotes presence, participation and achievement; educational institutions provide support to students who are rejected, weak, vulnerable; teachers are prepared to work with diversity; teachers participate in professional development activities focused on inclusive education.

Education at an educational institution becomes inclusive when there is highly qualified support in the education process; all institutions, service providers involved in the work are implementing inclusive policy and practice; resources (also financial) are available; the role of specialist support is clear (also from special education institutions).

The policy of education becomes inclusive when the thought of promoting inclusive education is highlighted in important documents on education; older staff provides clear administration of inclusive education; inclusive practice is supported in educational institutions, which is consistently formulated and shown by all members of administration at all levels; administration of all levels does not argue the inclusive practice at educational institutions.

The education system becomes inclusive when inclusion is considered a general principle that governs the policy and practice of all education; study programmes, systems of assessment take into account all the students; all agencies working with children, including healthcare and social services, understand and support political efforts to promote inclusive education; systems are introduced to monitor the presence, participation and achievements of all students (Ainscow \& Miles, 2009, 5-6).

R. Rieser and H. Peasley (Rieser \& Peasley, 2000, 6) believe there are important tasks in the promotion of obtaining inclusive education for students with special needs: work with parents, creation of partnership schemes; development of the basis of the educational institution focusing on the possibility to provide practical support to students so that as many parents as possible feel confident that the educational institution is able to satisfy the needs of their 
children; the development of knowledge and skills of the educational institution staff, administration, specialists working with students with special educational needs; cooperation with all institutions, organizations involved in the process of educating students with special educational needs. S. Pijil and C. Meijer share a similar opinion stating that inclusive education is a structure to provide specialized help at an educational institution, other support systems, decentralization and cooperation among educational institutions (Pijl \& Meijer, 1997, 12).

In order for the learning process (policy and practice) at an educational institution to become inclusive, M. Ainscow, A. Dyson and S. Weiner state the necessity to be clear on what is understood by inclusive education, to mobilize all available human resources in order to overcome obstacles in the learning process and to ensure participation, to provide different kinds of proof of the possibility of good practice, to encourage teachers for further inclusive work, to carefully plan additional possibilities of providing support to students who need it, to accordingly train support providers, to understand that inclusive education can be implemented in various ways but all these ways are united by the organizational structure with a positive perception of student diversity, to understand that the leaders working with their colleagues at educational institutions have a central role in promoting inclusive culture (Ainscow, Dyson, \& Weiner, 2013).

The school administration attitude and understanding is very important in the issue of inclusion (Pop, Powell, Miljevic, \& Crighton, 2009). The role of administration in the development of the inclusive education process at an educational institution is to guarantee the satisfaction of the rights of students with special needs to inclusion, to maintain inclusive policy in the activity of the educational institution, to provide all those involved in the learning process with information on the special needs of the students, to allocate funding for satisfying special needs, to guarantee accessibility of the educational institution (Department of education, 2011).

S. Peters (Peters, 1999) states that good administration of an educational institution determines the mood in the whole process of inclusive education. The role of administration in the development of an inclusive education process can be viewed from four perspectives: the vision and work order of the educational institution, the structure and organization of work of the educational institution, staff training, providing with resources for work. Administration should have a positive attitude to inclusion, the work of teachers in a corresponding environment must be supported: teachers who work well must be positively evaluated, help must be provided if things go wrong and time must be given for teacher interaction, for planning the work of teachers, solving cooperation problems, participation in support team meetings and adaptation of materials. Teachers who have the support of the educational institution administration are always more 
successful in the times of change. Administration must create a supportive environment for the inclusion requirements, organize staff training, professional development and the opportunities for professional development (Expert Panel on Literacy and Numeracy Instruction for Students with Special Education Needs, 2005, 113).

There are golden rules approved by teachers all over the world - for a learning process to be inclusive, involvement of all students is important, interaction, good process management, experience planning, personal learning plans, personal help, the use of technical aids, behaviour management, everybody's work together (UNESCO, 2001). For development of the inclusive processes, a team leader approved and respected by all, able to take responsibility and risk must be chosen, a general understanding of how the support team is going to work at the educational institution must be created, each team member must be encouraged to take responsibility for participation in the team work, open communication must be established, constantly maintaining open relationships, and to admit that disagreements among team members are a part of the cooperation process, ways of constructive conflict resolution must be created (Danielsa \& Steforda, 1999; Reid, 2006; Glynis, 2006, 9-11).

The process of inclusion at the educational institution must also be supported by the students, parents, other educational institutions and higher education institutions (Expert Panel on Literacy and Numeracy Instruction for Students with Special Education Needs, 2005, 112). M. Giangreco, S. Broer and S. Edelman point out that a lack of support for professionals at an educational institution can lead to a crisis because the educational institution employees do not understand what to do (Giangreco, Broer, \& Edelman, 2003, 168). The make-up of the support team specialists of the educational institution - speech and language pathologist, psychologist, social pedagogue, special education pedagogue, medical specialist etc. - may vary depending on the needs and circumstances of the students of the specific educational institution (Hunt, Doering, Hirose-Hatae, Maier, \& Goetz, 2003; Vasilevskis, Falka, b.g.; Expert Panel on Literacy and Numeracy Instruction for Students with Special Education Needs, 2005, 114). The educational institution administration and support team specialists must work as a team, "must develop a plan of measures for the implementation of a further inclusive education process of the educational institution, for providing the support in education" (Apeirons, 2007) where the measures for educational support include determining and assessment of the needs of a student; consultations and support for all students, including the students with special needs, professional development, consultations and support for teachers, the students' parents and the specialists; specialist consultations and services, also attracting specialists from other institutions; technical aids and equipment (if necessary); an opportunity to study using sign language and the services of an 
interpreter (if necessary); transportation services (if necessary, also with an accompanying person); assistant services, etc.

For effective cooperation of the support team specialists, teachers, parents and other staff of the educational institution, all the persons significant to the student with special needs must be involved in the inclusion process. Active involvement of the students' parents and other significant persons in the work of the support team improves the effectiveness of the team's work; for the parents it is also important to feel that their input is valuable in the working process of the educational institution team (Expert Panel on Literacy and Numeracy Instruction for Students with Special Education Needs, 2005, 114). During the meetings of the student and the support team of the educational institution it is advised to hear the student's thoughts and to include the student in making important decisions that affect the student; the student's "advocate" must be allowed to speak if the student themselves is afraid to speak or cannot due to other problems; the student may need help in writing their thoughts if it is easier than speaking; an adult employee of the educational institution who shows a positive tendency towards the student could be included in the conversation; similar advisers or groups of advisers could be included, promoting the participation of people; it is necessary to obtain assurance that everything is clear and correctly understood by the student or the young person (Bibby, Davey, Hudson-Vaux, Miller, Morling, \& Stitt, 2005).

It is necessary to arrange a class or just a room in the educational institution that could be used as a room for the meetings and work of the support team, at the same time, a as a working room for the specialists and individual work after class a resource room. The room must meet the specific problems of the students: if the educational institution has students with vision problems, there should be good lighting and sound equipment; if there are students with hearing problems, the room must have sound isolation, good lighting so that students could read the teacher's lips and signs; if there are students with mental development disorders, the level of noise and other stimulators must be low because it can impede concentration (Apeirons, 2007; Friend \& Bursuck, 2002; Kirk, Gallagher, \& Anastasiow, 2000; The Utah Education Association, 2009). The resource room can be used to provide the special needs student with individual specialist consultations, for individual classes with specialists and individual acquisition of various learning strategies, for the others involved - for consultations, education, supervision, support team meetings etc. (Kirk, Gallagher, \& Anastasiow, 2000.

Cooperation of the support team specialists has a huge importance, regular meetings where work strategies with specific special needs students and their effectiveness are discussed with the participation of study subject teachers and parents. When deciding to apply a new work strategy, the person to implement the strategy must be given at least a month of time for its implementation, then 
the results obtained are analyzed during another meeting: detailed description of activities tried, detailed report on the student's reaction to the new activities, any new information must be provided that was received during the implementation of the strategies, information on any changes (for example, changes in family circumstances, stands that can affect the effectiveness of intervention), as well as any questions and uncertainties that emerged during the testing of the strategy. If the new strategies proved to be effective, the meeting members can agree on the continuation of these strategies regarding the specific student, but if the strategies did not produce results, new strategies are developed and tried (Glynis, 2006, 911). The support team specialists and parents decide on the necessity of support measures, application and effectiveness in the learning process of specific students (Giangreco, Broer, \& Edelman, 2003, 168), decide whether the student needs an individual support person if the student's behaviour disturbs the class, the student cannot take care of themselves, does not have independent mobility, poses a safety risk to themselves or other students, if constant support is needed in a specific field (Giangreco, Broer, \& Edelman, 2003, 171).

In an inclusive educational institution, various support measures are used during the learning process and tests depending on the specific special needs of the students. The support teams of the educational institution have an important role in evaluation of the student's special needs and choosing the necessary support measures to eliminate or reduce the obstacles caused by each specific disorder or disorders. A correct decision will provide the student with an opportunity to show their knowledge and skills without suffering from limitations caused by their health or developmental disorders. The task of the educational institution support team is "to ensure that the decision made on the support measures minimizes as much as possible the risk of a student receiving an inadequate grade on an ordinary day or for a test" (Vasil̨evskis, Falka, year not indicated). The support teams of educational institutions should provide support for the teachers working in the class, help decrease the difficulties that the student encounters in class, after classes, to support students and parents, provide an opportunity to cooperate, to consult and exchange information and knowledge in order to identify strategies that can improve learning achievements of the student.

When starting the creation of the inclusive educational institution learning process, the support team specialists and the educational institution administration must analyze the existing basic training of the teachers of the educational institution: the level of knowledge and skills of work with students who have special needs, which can be very different, the opinions existing among staff, views on their own readiness and that of the educational institution for work in an inclusive learning process, for teachers usually have a lot of knowledge and skills necessary to work with all students but do not have real confidence about their correctness; professional development of teachers is needed that would give the 
teachers an additional feeling of confidence about the correctness of their work and the understanding that the inclusive work practice is more than just differentiation, that would allow acquiring new work strategies, learn to cooperate with everyone involved in the inclusion process, to work for one shared aim in a united team, instead of the usual responsibility for and emphasis on only the results of their personal work and not taking responsibility in general.

Each support team specialist in the educational institution has their own specific responsibilities. One of the support providers to a student with special needs in the learning process can be a special education pedagogue (Jonsson, 2006, Janney \& Snell, 2003, 103, Giangreco, Broer, \& Edelman, 2003). The work of a special education pedagogue in the educational institution support team and in the educational institution in general is determined by the description of work responsibilities prepared by the Ministry of Education and Science (IZM, 2009). Special education teacher helps the pedagogue of a general education institution during work with students who have pronounced physical or mental developmental disorders (vision, hearing, neuropsychological, somatic, language disorders) or learning disorders, implementing a special primary education programme for the students included; implement the education programme in a specific study subject according to the State Education Standard and according to the health and level of development of each student; agree on the content of their work with the teachers of the corresponding study subject; determine individual work hours and participation in classes with other students; in cooperation with the study subject pedagogues, class masters, educational institution support team staff and educational institution administration, analyze the learning, psychological and adaptation problems of each student and determine the learning methods to be applied to solving such problems; perform individual work with students to explain the learning material that is unclear, to create motivation to learn and to develop cooperation and communication skills, help students to prepare for classes and after class activities, create their self-care skills; cooperate with the students' parents in order to understand the students' problems and to inform the parents of the student's difficulties at the educational institution to search for solutions together; perform the analysis of the dynamics of students' development and self-analysis of one's own work; plan one's work and inform about the results of the work following the order established by the educational institution etc. (IZM, 2009).

In cooperation with subject teachers, the special education pedagogue consults teachers on how to use materials and methods that will suggest the correct answer to the student (simplifying the tasks and allowing to participate in class with the sense of a job well done); how to encourage for further work when providing comments about a correct or incorrect answer, an assessment of the answer, focusing on the correct answers; how to motivate a student to work, 
finding the correct level without overcomplicating or oversimplifying the tasks; how to systematically move from the unknown to known, slowly, step by step; how to avoid forgetting, by repeating at frequent intervals, returning to the learned material at specific time intervals; how to gain more time for exercises using the teaching of peers, allowing classmates to help; how to use specific items in the learning process instead of abstract concept; how to work flexibly, using various methods and techniques in the learning process (Vasilevskis, Falka, year not indicated).

Another specialist working on the educational institution support team and providing support to those involved in the inclusion process is an educational psychologist, the description of work responsibilities has also been approved by order No. 425 of 16 October 2009 of the Ministry of Education and Science (IZM, 2009). The responsibilities of an educational psychologist include psychological analysis of students, including observation in class and after class; analysis of the students' psychosocial environment; consulting students, parents and pedagogues in cases of students' psychological problems; development of main principles of promoting the students' mental development in case of difficulties with acquisition of learning material and developing recommendations for pedagogues and parents for providing support; ensuring prophylactic measures: educating the students' parents and pedagogues on the issues of psychology; participation in activities aimed at reducing the influence of unfavourable factors found in psychosocial studies at the educational institution; providing support to students during the adaptation process; preparation of written conclusions on the results of a psychological analysis or a consultation of students; cooperation with parents, informing them on the achievements and problems of the student at the educational institution, looking for solutions together; perform the analysis of students' development dynamics; plan one's work and inform about the results of the work following the order established by the educational institution etc. (IZM, 2009).

Work responsibilities of another support team specialist - the speech and language pathologist teacher - include improving the student's "spoken and written language development skills for complete acquisition of linguistic competences (requirements) put forward by the State Primary Education Standard; promote the growth of a student's self-esteem and provide support during the adaptation process; perform frontal diagnostics of a student's spoken and written language and reading skills; create groups for speech and language pathology exercises according to the student's age, language disorders and the level of mental development; if necessary, work with students who have spoken or written language disorders individually; consult students, parents and teachers in cases of spoken or written language disorders and developing recommendations for providing help to the students; prepare a written report on the development of 
a student's spoken and written language when a student is sent to the state or municipal medical pedagogical committee as well as in cases provided for in the normative acts or upon a written request of the parents; perform analysis of the students' development dynamics and self-analysis of one's own work; plan one's work and inform about the results of the work following the order established by the educational institution" (IZM, 2009) etc., which is set forward in order No. 425 of 16 October 2009 of the Ministry of Education and Science (IZM, 2009).

When beginning the implementation of inclusion of students with special needs in educational institutions, it is important to provide the support required by each student, and one of the ways of support could be pedagogues'/ teachers' assistants (Birkett, 2004; IZM, 2013). The author of the dissertation, while studying the practical work of introducing inclusive education at London educational institutions, observed that the task of a pedagogue's/ teacher's assistant based on the English experience (beginning with year 1990, the position of a teacher's assistant is introduced into the educational institutions of England) is: be together with the special needs student in class (especially mathematics and native language, decision on the other subjects is made by the support team depending on the student's needs); pass work tools and materials to the student with special needs, consulting with the teacher before the class; read to the student with special needs individually or in a small group and listen to the student's reading; play games with the student or a small group of students; check the student's with special needs work and help correct mistakes; work as a writer if necessary; help students with behavioural disorders change their attitude; explain words that the student does not understand, encouraging to find them in a dictionary; help a student with special needs to work with specialized computer software; supervise the process of performing practical work; help start unsuccessful work again; observe how the student is performing a task, getting involved only if the student cannot do it independently; prepare audio recordings and encourage to use a voice recorder for recording information as well as control what the student is recording; inform teachers about results and problems; help with planning and with preparation of reports; teach the student to spell, etc. (Fox, 2003, 2; Handbok of learning, 2003; Hanko, 1986).

In Latvia, model regulations of the general education institution teacher's/pedagogue's (both terms are used in Latvia) assistant's work were approved by the Ministry of Education and Science on 18 July 2003, amended and approved again on 16 October 2009 (IZM, 2009); they provide that the teacher's/pedagogue's assistant helps students with learning, social, psychological difficulties when implementing the primary education programme at general education institutions to promote the improvement of learning achievements, growing of their self-esteem and successful adaptation in the environment of the educational institution; in cooperation with the study subject 
teachers, class master, educational institution support staff (psychologist, social pedagogue, speech and language pathologist, medical specialist) and administration, analyze each student's learning, psychological and adaptation problems and determine the methods to be applied to solving such problems; ensure the students' (refugees, asylum seekers, nationals of third countries of Europe) inclusion into the education system of Latvia; perform individual work with students to explain unclear learning material, create motivation to learn and develop cooperation and communication skills; follow the instructions of the corresponding study subject teacher, class master and educational institution administration; prepare information on the achievements and problems of the student at the educational institution; together with the study subject teacher, plan the work to be done in class - lesson aims, material to be taught, teaching methods to be applied; perform analysis of student development dynamics and selfanalysis of one's work; plan one's work and inform about the results of the work following the order established by the educational institution etc.

In order for a student with special needs to be successfully included into the education process and acquire social skills, it is important to develop an individual education plan and implement it in the learning process (Kirk, Gallagher, \& Anastasiow, 2000). To create an individual education plan means to adapt the education process to the specific character of the student's cognition processes, experience, skills in order to acquire the requirements of the education standard and study subject programmes (Snowman \& Biehler, 2000, 181; Kirk, Gallagher, \& Anastasiow, 2000, Hodkinson \& Vickerman, 2009). Individual general developmental and educational programmes that correspond to the guidelines of special primary education programmes but still refer to a primary education programme for a specific school year, are developed by the support team specialists and study subject teachers.

\section{Conclusions}

1. To ensure optimal development of students with developmental disorders, the administration of the educational institution, support team specialists, teachers (and students' parents) must consider the following: the aim of education in general and to what extent a specific student will be able to achieve it; how the unity of learning and upbringing in the education process is expressed in the education of a specific student; the abilities of a specific student and related developmental possibilities; developmental disorders of a specific student to be aware of and the kind of support that helps them learn more successfully and feel better; whether the teacher sees the achievements of the student, gives recognition and helps the student be aware of them too (Florian,2008; North \& McKeown, 2005). 
2. Inclusive education cannot be perceived as the only possible solution; the real situation of each student with special needs must be assessed and the ability of the chosen educational institution to provide the student with the necessary support. When including a student with special needs into a general education institution, the student's situation cannot worsen and the amount of necessary help received cannot decrease compared to what the student would receive studying at a specialized educational institution, which is also an expression of humanity in the educational process.

\section{Discussion}

The theoretical study has shown that when beginning the activity of an inclusive educational institution, the administration of the educational institution must perform substantial analysis of the existing situation, must perform sufficient preparation work in order to ensure real support, based on the needs of the students and teachers. It is important that the educational institution employees receive all the necessary resources for their professional activity, including paid work hours, to agree with each other on their work, for consultations with each other and cooperation. In practice, it is impossible for specialists with part-time workloads to actually organize the work of a support team as a team.

\section{References}

Ainscow, M. (2004). Developing inclusive education systems: what are the levers for change? Downloaded from https://www.uam.es/personal pdi/stmaria/sarrio/DOCUMENTOS,\% 20ARTICULOS,\%20PONENECIAS,/Developing\%20educational\%20inclusive\%20seti ngs.pdf

Ainscow, M., \& Miles, S. (2009). Developing inclusive education systems: how can we move policies forward? Downloaded from http://www.edu.am/DownloadFile/66engMel_Ainscow.pdf

Ainscow, M., Dyson, M., \& Weiner, S. (2013). From exclusion to inclusion: ways of responding in schools to students with special educational needs. Download from files.eric.ed.gov/fulltext/ED546818.pdf

APEIRONS (2008). Universālais dizains. Download from http://www.videspieejamiba.lv/lat/ universalais dizains/?doc $=102$

Bibby, A., Davey, M., Hudson-Vaux, D., Miller, S., Morling, E., \& Stitt, C. (2005). Supporting Children with Behaviour Difficulties. David Fulton Publishers Ltd.

Birkett, V. (2004). How to support and manage teaching assistants. Cambridge: LDA, UK.

Booth, T. (2000). INCLUSION IN EDUCATION: PARTICIPATION OF DISABLED LEARNERS. World Education forum. Downloaded from http://www.unesco.org/ education/wef/en-leadup/findings_inclusion.shtm

Birkett, V. (2004). How to support and manage teaching assistants. Cambridge: LDA, UK.

Cardona, G. (2011). Inclusive education: a special right? Commonwealth Education Partnerships. Downloaded from Gordon - Cardona - article. pdf 
Celma-Zīida, D. (2013). Jaunās tendences un izaicinājumi profesionālās izglītības iestādēs. Krājumā '"Pārmaiṇu un kvalitātes vadība izglītības iestādē". Rīga

Danielsa, E. R., \& Steforda, K. (1999). Ieklaujošas klases radī̌sana. Rīga: Sorosa fonds Latvija.

Department of education (2011). A RESOURCE FILE for schools to support children with Special Educational Needs. Download from http://www.deni.gov.uk/resource_file.pdf

Dyson, A. (2010). Developing inclusive schools: three perspectives from England. DDS - Die Deutsche Schule 102 (2/2010), p. 115-129

Education White paper 6. (2001). Special Needs Education. Building an inclusive education and training system. PRETORIA: ELSEN Directorate, Department of Education. Downloaded from http://www.info.gov.za/whitepapers/2001/educ6.pdf

Expert Panel on Literacy and Numeracy Instruction for Students With Special Education Needs (2005). Educatiion for All. Downloaded from https:/www.edu.gov.on.ca/eng/ document/reports/speced/panel/speced.pdfL

Fox, G. (2003). Handbook for Learning Support Assistants. Teacher and Assistants Working together. London: David Fulton Publishers.

Friend, M., \& Bursuck, W. D. (2002). Including students with special needs. Boston: Allyn and Bacon.

Giangreco, M. F., Broer, S. M., \& Edelman, S. W. (2003). The Tip of the Iceberg: Determining Whether Paraprofessional Support is Needed for Students With Disabilities in General Education Settings. The Foundations of Inclusive Education: A Compendium of Articles on Effective Strategies to Achieve Inclusive Education (Second Edition). Diane Ryndak and Douglas Fisher, Editors. TASH. Baltimore. USA.

Glynis, H. (2006). Identifying children with Special Needs: Checklists and Action Plans for teachers. Corwin Press.

Handbook for Learning (2003). Support Assistants. Ed. Fox G. D. Fulton publishers.

Hodkinson, A., \& Vickerman, P. (2009). Key Issues in Special Educational Needs and Inclusion. Great Britain by CPI Antony Rowe, Chippenham, Wiltshire.

Hunt, P., Doering, K., Hirose-Hatae, A., Maier, J., \& Goetz, L. (2003). Across -Program Collaboration to Support Students With and Without Disabilities in a General Education Classroom. The Foundations of Inclusive Education: A Compendium of Articles on Effective Strategies to Achieve Inclusive Education (Second Edition). Diane Ryndak and Douglas Fisher, Editors. TASH. Baltimore. USA.

Jackson, L., Ryndak, D. L., \& Billingsley, F. (2003). The Foundations of Inclusive Education: A Compendium of Articles on Effective Strategies to Achieve Inclusive Education (Second Edition). Diane Ryndak and Douglas Fisher, Editors. TASH. Baltimore.USA.

Jonssons, T. (2006). Iekḷaujošā izglìtība. Rīga: Invalīdu un viṇu draugu apvienība" Apeirons." Janney, R. E., \& Snell, M. E. (2003). How Teachers Include Students with Moderate and severe Disabilities in Elementary Classes: The Means and meaning of Inclusion. The Foundations of Inclusive Education: A Compendium of Articles on Effective Strategies to Achieve Inclusive Education (Second Edition). Diane Ryndak and Douglas Fisher, Editors. TASH. Baltimore. USA

Kirk, S. A., Gallagher, J. J., \& Anastasiow, N. J. (2000). Educating Exceptional Children. Boston. New York: Houghton Mifflin Company.

IZM (2009). Par pedagoga darba pienākumu aprakstu paraugu apstiprināšanu. Rīkojums Nr. 425. Pieejams: www.izm.gov.lv/images/ped_modelis/Skolotajs_amata_apraksts.pdf 
IZM (2013). Izglītības attīstības pamatnostādnes 2014.-2020. gadam. Pieejams https://m.likumi.lv/doc.php?id=266406

Kirk, S. A., Gallagher, J. J., \& Anastasiow, N. J. (2000). Educating Exceptional Children. Boston. New York: Houghton Mifflin Company.

Mitchell, D. (2010). Education that fits: Review of international trends in the education of students with special educational needs. Downloaded from http://www.educationcounts. govt.nz/publications/special_education/education-that-fits-review-of-internationaltrends-in-the-education-of-students-with-special-educational-needs/chapter-eleveninclusive-education

Nīmante, D. (2008). Bērnu ar speciāalām un ìpašām vajadzībām ieklaujoša izglītība Latvijā: vēsturiskais un mūsdienu konteksts. Sociālā pedagoǵija. Promocijas darbs pedagoǵijas doktora zinātniskā grāda iegūšanai. Rīga: Latvijas Universitāte.

Noteikumi par Latvijas Nacionālo attīstības plānu 2007.-2013. gadam (2006). Pieejams http://likumi.lv/doc.php?id=139505

Peters, J. (1999). What is Inclusion? Downloaded from fisherpub.sjfc.edu/ur/vol2/iss 1/5/

Pijl, S. J. P., \& Meijer, C. J. W. (1997). Factors in inclusion: a framework. Inclusion. Implementation and approaches. London and New York: Routledg. 8-13 p.

Pop, D., Powell, S., Miljevič, G., \& Crighton, J. (2009). School Governance and social inclusion. South East Europe Cross-countries Survay of Principals views. Fund an open society. Serbia: University of Lubljana.

Ras, S. (2008). Inclusive Education. An overview of international experiences and approaches. Downloaded from http://www.lightfortheworld.nl/docs/policies-and-papers/inclusiveeducation.pdf?sfvrsn $=8$

Reid, G. (2006). Learning styles and inclusion. P. Chapman Publishing.

Rieser, R., \& Peasley, H. (2002). Disability Equality in Education. Inclusion in Schools. Downloaded from www.msmt.cz/file/11800_1 $1 /$

Snowman, J., \& Biehler, R. (2000). Psychology. Applied to Teaching. USA: Houghton Mifflin Boston.

The Utah Education Association (UEA) (2009). Necessary resources. Downloaded from http://en.wikipedia.org/wiki/Inclusion_(education)

Turnbull, R., Turnbull, A., Shank, M., \& Smith, S. J. (2004). Exceptional Lives. Special Education in todays schools. USA: Pearson Prentice Hall.

UNESCO (2009). Towards Inclusive Education for Children with Disabilities: A Guideline Editor: Daniel Calderbank .Bangkok. Downloaded from http://www.uis.unesco.org/ Library/Documents/disabchild09-en.pdf.

UNICEF (1998). Education for all? The MONEE Project CEE/CIS/ Baltics, Regional Monitoring Report No. 5. Florence.

UNESCO (2001). Understanding and Responding to Children's Needs in Inclusive Classrooms.

UNESCO (2005). Guidelines for Inclusion: Ensuring Access to Education for All. France: Paris. 15.-16. 1pp.

Vasiḷevskis, G., \& Falka, S. (b.g.). Atbalsta komandas darba organizācija izglītības iestādē Pieejams visc.gov.lv/specizglitiba/dokumenti/metmat/atb_komandas_organizacija.pdf

World Health Organization (2011). World report on disability 2011. Downloaded from www.who.int

Wolfendale, Sh. (1987). Primary schools and Special Needs. Policy, planning and provision. Biddles LTD., Guildford and King's Lynn. 